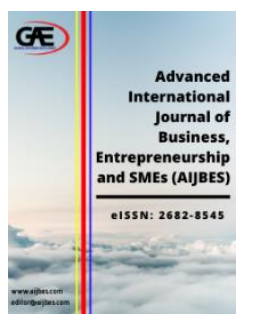

\author{
ADVANCED INTERNATIONAL JOURNAL OF \\ BUSINESS, ENTREPRENEURSHIP AND SMES \\ (AIJBES) \\ WWw.aijbes.com
}

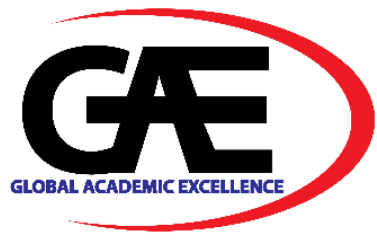

\title{
MARKETING STRATEGY EVALUATION OF MRT JAKARTA'S MOBILE APPLICATION USING MARKETING 4.0 CONCEPT
}

Gideon Satria Putra Sugiyanto $^{1 *}$, Agung Wicaksono ${ }^{2}$

1 School of Business and Management, Bandung Institute of Technology, Indonesia

Email: gideon_sugiyanto@sbm-itb.ac.id

2 School of Business and Management, Bandung Institute of Technology, Indonesia

Email: agung.wicaksono@sbm-itb.ac.id

* $\quad$ Corresponding Author

\section{Article Info:}

Article history:

Received date: 20.11 .2020

Revised date: 06.12.2020

Accepted date: 15.12 .2020

Published date: 22.12 .2020

\section{To cite this document:}

Sugiyanto, G. S. P., \& Wicaksono, A. (2020). Marketing Strategy Evaluation of MRT Jakarta's Mobile Application Using Marketing 4.0 Concept. Advanced International Journal of Business, Entrepreneurship and SMEs, 2 (6), 43-54.

DOI: $10.35631 /$ AIJBES.26005.

This work is licensed under CC BY 4.0

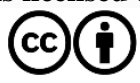

Abstract:

A mobile application has become a vital tool to provide better service and build relationships with customers in the digital age. MRT Jakarta responded to the trend by launching MRT-J mobile application. A study to evaluate the effectiveness of marketing strategy for MRT-J involving 205 respondents of questionnaires was developed following the Five As Framework from Marketing 4.0 concept (Kotler, Kartajaya, and Setiawan, 2017). The result revealed that MRT-J has a superlative affinity. However, the Company needs to improve the attraction, curiosity, and commitment level. According to the industry archetype, the evaluation of brand productivity metrics reported that MRT-J mobile application has a Trumpet pattern. A combination of conventional (offline) and digital (online) marketing is suggested to increase the number of downloads by improving the stage of Aware, Appeal, Ask, and Act.

Keywords:

Customer Journey, Five As Framework, Marketing 4.0, MRT Jakarta, Mobile Application

\section{Introduction}

Indonesia shows a trend of enormous increment of internet users year by year. In 2017, APJII reported that the number of internet users reached 142 million people, or 54,68\% of the total population (APJII, 2017). The numbers increased significantly a year later, covering 171,17 million users or $64,87 \%$ of the total population (APJII, 2018). The continuously rising number of internet users has also triggered the growth of smartphone users in the nation. People do not 
Volume 2 Issue 6 (December 2020) PP. 43-54 DOI 10.35631/AIJBES.26005

only use the smartphone as a mere communication device. Instead, the smartphone has become an integral part of the lifestyles, enabling people to communicate, look for information, entertainment, and even purchase transactions through digital interaction (Paul \&Rosenbaum, 2020; Arya, V., Sethi, D., \& Paul, J., 2019). It becomes vital for companies to develop a mobile application to connect them with the users and provide a better quality of services (Jasiulewicz \& Waskowski, 2020).

PT MRT Jakarta (Perseroda) or MRT Jakarta responded to the trends positively by launching a mobile application called MRT-J in 2019. MRT-J was initially introduced to help users check train departure schedules, the interconnection between modes, and other than MRT Jakarta's operation-related information. Simultaneously, the transaction is executed through a multi-trip or single ticket, which has been perceived as beneficial and easy to use (Ayuverda \& Permana, 2020). The application was then enhanced in 2020 by enabling the users to purchase MRT Jakarta's ticket online and use the QR system to experience a seamless transaction.

The COVID-19 pandemic that entered Indonesia in March 2020 had made the existence of a mobile application for transaction becomes more vital than before. People avoided direct contact for their transactions to prevent the contagion of the COVID-19. Consequently, the number of MRT Jakarta's passengers who used the MRT-J was expected to increase significantly. On the business side, PT MRT Jakarta (Perseroda) also tries to be agile in dealing with the performance issues since the number of MRT Jakarta's dropped dramatically during the COVID-19 pandemic. PT MRT Jakarta (Perseroda) launched the Beyond Normal Strategy to help the business survive and revoke from the COVID-19 pandemic. One of the strategy's crystallization is through non-fare box and digitalization business that requires MRT-J mobile application as the tool.

It is crucial to evaluate the current marketing strategy performance to develop a better strategy that can increase the brand penetration in the market and increase the download numbers to optimize the commercialization of MRT-J mobile application for other purposes besides MRT Jakarta's information and ticketing,

\section{Research Objectives and Methodology}

This research's objective was to evaluate the effectiveness of the current strategy in marketing the MRT-J mobile application so that the targeted audience could know the mobile application's existence, download, use, and recommend it to other people. The evaluation is based on the Five As Framework from Marketing 4.0 Concept, which introduces five stages of customer journeys, which are Aware, Appeal, Ask, Act, and Advocate (Kotler, Kartajaya, and Setiawan, 2017).

The study was conducted using a quantitative study by gaining primary data from the MRT Jakarta's users through a questionnaire distributed online (email and social media) from 28 October 2020 to 1 November 2020. The questionnaire was developed in five parts: demography, customer behavior in MRT Jakarta for mobility, customer journey, MRT-J mobile application development, and closing. The types of question's answer forms ranged from Likert scale, Guttman (agree or disagree), multiple choices, multiple answers, and open questions. The questionnaire used a random sampling method whose sample size is calculated using Slovin Formula of $\mathrm{n}=\mathrm{N} /\left(1+\mathrm{Ne}^{2}\right)$ with $\mathrm{n}=$ sample size, $\mathrm{N}=$ population, and $\mathrm{e}^{2}=$ desired margin error. In this study, the population $(\mathrm{N})$ refers to the daily users of MRT Jakarta, which 
Volume 2 Issue 6 (December 2020) PP. 43-54 DOI 10.35631/AIJBES.26005

is 89.645 in 2019 , and the desired margin of error (e) was $10 \%$. The calculation revealed that the sample size required to be at least 100 samples of respondents. However, the questionnaire eventually covers insights from 250 respondents, with 205 of them were valid.

\section{Literature Review}

\section{Marketing 4.0}

Marketing 4.0 is the product of dynamic changes caused by turbulence. On the markets, the competitive essence of global competition is demanding. Customers and the rapid introduction of emerging innovations and cutting-edge technologies and innovations in marketing. It can be seen as an odd and speedy thing (Swieczak, 2017).

Marketing 4.0 acknowledges the condition where customers have an incredible intensity in connecting with brands through online channels without entirely abandoning offline ways (Wereda and Wozniak, 2019). Consequently, the marketplace becomes more crowded with the existing and new brands, which leads to tighter competition among the players. Kotler, Kartajaya H, and Setiawan I (2017) suggested that brands have to uphold authenticity as their differentiator in the overly increasing of contents and transparency of information. Brands do not only have to emphasize customer-centric focus but also to ensure a smooth customer journey, both offline and online.

Thus, ensuring the awakening of audience awareness toward a brand until the final stage is more vital than ever (Gregor, 2002). Marketing also becomes one of the key drivers for all business in the context of The Industrial and Marketing 4.0 due to the advancement and broad application of technology, which increase efficiency for nearly all products and give users more list of options (Yeo, N.C.Y. Pepin, H. \& Yang, S.S. 2017 and Jara, 2012).

Several significant changes that interfere with the way marketing strategy should be built, as stated by Fucui, M (2018), are:

a. the greater sense of ownership that customers have toward a brand

b. the importance of internal communication of the brand value to the employees to born brand advocators from the internal of the organization

c. carefully retain communication with channel partners such as but not limited to other companies and public authorities that should be done to continuously understand their interest and expectations so that companies may develop strategic marketing to address it

d. vigorously market the visions of the brands to all shareholders and stakeholders instead of just focusing on the functionalities

As the brand image is the consumer's viewpoint, the brand name has a paramount role in the consumer's viewpoint. The brand names often work more than just an identity and define the particular intrinsic value of the products (Wanke, M., Herrmann, A., \& Schaffner, D, 2006). Every product tries to reach out to customers by using different methods. For example, firms tend to use a combination of marketing methods such as the medium of distribution, public relationships, expenses, marketing, and core service (Goi, M. T., Goi, C. L., \& Wong, D, 2014). Rajagopal (2018) argued that personality, image, reputation, and trust are vital elements for evaluating a brand's identity. Tsaur, S. H., Yen, C. H., \& Yan, Y. T. (2016) enriched the study by introducing five-element concepts: image, quality, personality, awareness, and culture. 
Above all, it is unanimous that word of mouth has more power than paid advertisement since people prefer to have a human-centric approach in receiving recommendations (Verma, 2020). With the increasing power and effectiveness of word of mouth in Marketing 4.0, the brand has to extend the target from deal closing or customer's purchase into post-purchase satisfaction. One factor that positively influences the customer's satisfaction is brand identity (Hearne, M., Bhattacharya, C. B., \& Gruen, T, 2005; Carrol \& Ahuvia, 2006; Berger \& Heath, 2007; Ruvio, 2008).

\section{Five As Framework and The Marketing Productivity Metric}

Five As Framework was introduced by Kotler, Kartajaya H, and Setiawan I. (2017) in Marketing 4.0 to define and evaluate customer journey. The Framework embraces the connectivity era into the context of the customer journey by introducing five stages, which are Aware, Appeal, Ask, Act, and Advocate. Aware is the first stage where customers are surrounded by many brands even without them looking for them. It becomes the first stage where a brand can enter the customer path and proceed to the next stages. Once audiences are aware of the brand, the brand may continue to the second stage, Appeal. Brands have to offer unique values or selling points to be appealing to the customers. In this stage, customers are continuously exposed to information related to the brands. Brands have to share adequate information to trigger curiosity but not too much to prevent customers from heading to the next stage, which is Ask. In this stage, customers respond to their curiosity by directly or indirectly asking or looking for more information about the brand. Once the brand well addresses the customers' curiosity or questions, customers may continue to the next stage, which is Act where the customers decide to use the brand. However, it should not be the final goal for the brands. Customers have to be satisfied before, during, and even after purchase. The goal is to ensure that the customers step further to the last stage, the Advocate. In the last stage, customers enjoy the brand that fulfills their expectations and actively recommends others. The advocate stage, however, is unique for several brands in a particular industry archetype pattern. The Advocate stage can be filled by both the brand's users or those who settle with the Act stage and those who may skip the Act stage and directly proceed to advocate. However, as it is stated by Kotler, Kartajaya H, and Setiawan I. (2017) the Five As process might not be linear and does not have to be passed by all brands and customers. Several stages might be skipped for several brands or customers and directly proceed to Act such as the FMCG products due to impulsive buying. Customers may skip Act and directly go to the Advocate stage when the quality of the product is proven but it is considered luxury products.

Kotler, Kartajaya H, and Setiawan I. (2017) also introduced two productivity metrics in Marketing 4.0, which are Purchase Action Ratio (PAR) and Brand Advocacy Ratio (BAR). PAR is a measurement of how well a brand converts people who are aware of purchase action. On the other hand, the BAR is a measurement of how well a brand converts people who are aware of becoming loyal advocators. The formulas for PAR and BAR are as follow:

- $\quad \mathrm{PAR}=$ Purchase Action / Spontaneous Awareness

- $\mathrm{BAR}=$ Spontaneous Advocacy / Spontaneous Awareness (Kotler et al., 2017). 


\section{Result and Discussion}

\section{Respondents' Demography}

The majority of the respondents are young professional around 25-31 years old (48,8 \%) and generation $\mathrm{Z}$ whose ages is around 18-24 years old (23,9\%). Among all respondents, $42,9 \%$ of them hold a bachelor degree, and the rest are senior high school graduate and master degree (each 15,6\%), and also doctoral $(5,4 \%)$. The two biggest groups based on occupation classification revealed that most of the respondents work as private employees $(40,5 \%)$, and the others are students $(30,2 \%)$. There were $28,3 \%$ of the respondents earn more than IDR 11 million monthly, 22,9\% earn less than IDR 2,8 million monthly, 22\% earn around IDR 7-11 million monthly, 20,5\% earn IDR 4,25-7 million monthly, and the other 6,3\% earn IDR 2,84,25 monthly. It shows that MRT Jakarta users vary from those whose earn are below average minimum wage of DKI Jakarta Province, which is IDR 4.276.349 in 2020 and way above it. However, classifying from the monthly expense following World Bank's standard for Indonesia (World Bank, 2020) reported that most of the respondents belong to the social-economic status of the middle class who spend IDR 1,2-6,0 million a month $(48,8 \%)$ and upper class who spend more than IDR 6 million a month $(22,9 \%)$. It may indicate that MRT Jakarta has become a preferable option for modern public transportation for middle and upper classes in Jakarta to facilitate mobility other than using private vehicles.

\begin{tabular}{|c|c|c|}
\hline Sociodemographic & Variable & Total Respondents \\
\hline \multirow[t]{8}{*}{ Age } & $<18$ & 8 \\
\hline & $18-24$ & 49 \\
\hline & $25-31$ & 100 \\
\hline & $32-38$ & 22 \\
\hline & $39-45$ & 13 \\
\hline & $46-52$ & 7 \\
\hline & $53-59$ & 4 \\
\hline & $>59$ & 2 \\
\hline \multirow[t]{5}{*}{ Education } & Senior high school & 32 \\
\hline & Diploma & 11 \\
\hline & Bachelor degree & 129 \\
\hline & Master degree & 32 \\
\hline & Doctoral degree & 1 \\
\hline \multirow[t]{7}{*}{ Occupation } & Student & 62 \\
\hline & Civil Servant / Army / Police & 9 \\
\hline & Government-Owned Company & 19 \\
\hline & Private Company & 83 \\
\hline & Entrepreneurs & 16 \\
\hline & Freelancer & 10 \\
\hline & Others & 6 \\
\hline \multirow{5}{*}{$\begin{array}{l}\text { Monthly income } \\
\text { (IDR) }\end{array}$} & $<2,8$ million & 47 \\
\hline & $2,8-4,25$ million & 13 \\
\hline & $4,25-7$ million & 42 \\
\hline & $7-11$ million & 45 \\
\hline & $>11$ million & 58 \\
\hline Monthly expense & $<354$ thousand & 11 \\
\hline
\end{tabular}


Volume 2 Issue 6 (December 2020) PP. 43-54 DOI 10.35631/AIJBES.26005

\begin{tabular}{|c|c|c|}
\hline \multirow{3}{*}{$(\mathrm{IDR})$} & $354-532$ thousand & 16 \\
\cline { 2 - 3 } & 532 thousand $-1,2$ million & 31 \\
\cline { 2 - 3 } & $1,2-6$ million & 100 \\
\cline { 2 - 3 } & $>6$ million & 47 \\
\hline
\end{tabular}

Figure 1: Respondents Sociodemographic

Source: (Author's Analysis, 2020)

\section{Five As Framework Evaluation Result}

Aware

Source: Author's Analysis (2020)

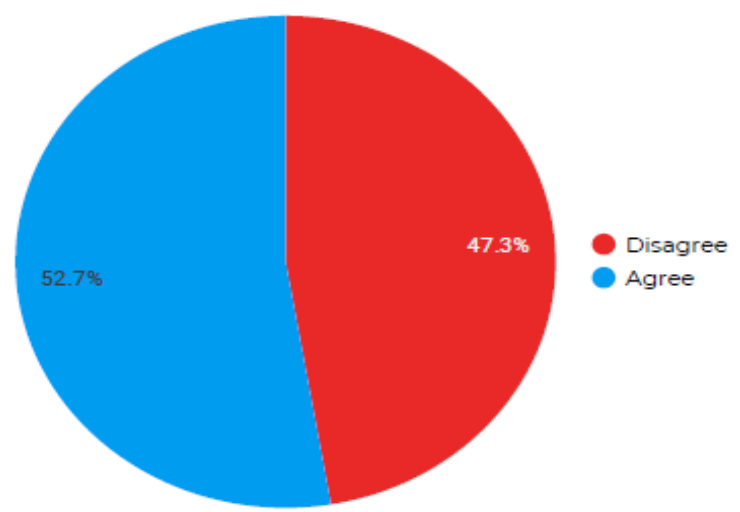

Figure 2: Stage of Aware

The Aware stage was evaluated by asking if the respondent has ever heard, seen, read about MRT Jakarta's mobile application. The result shown in Figure 2 reported the awareness of MRT Jakarta's mobile application reaches 52,7\%. It interprets as five out of ten people are aware of the mobile application. It translates that 5 out of 10 people have ever heard that MRT Jakarta has a mobile application. As stated above, the following stages of the Five As were still evaluated since the customer journey may not undergo the whole five stages and to observe the brand archetype produced from the evaluation.

\section{Appeal}

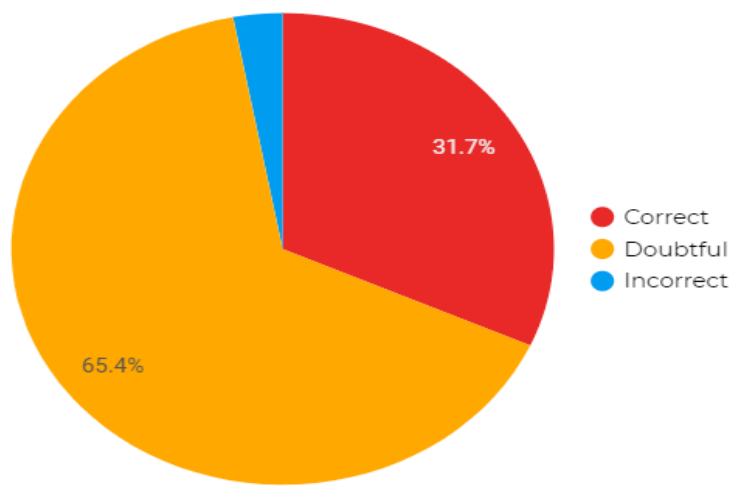

Source: Author's Analysis (2020)

Figure 3: Stage of Appeal 
Volume 2 Issue 6 (December 2020) PP. 43-54 DOI 10.35631/AIJBES.26005

To evaluate if MRT-J mobile application is an appealing brand for the targeted audience, the questioner tested respondents' knowledge about the name of the application that MRT Jakarta has. It is reported that only $31,7 \%$ of the respondents who were aware of the brands were confident to confirm that MRT-J is the valid name, most of the respondents $(65,4 \%)$ were not sure, and 2,9\% of the respondents did not know that MRT-J is the right name as shown in Figure 3. Decreasing score from Aware to Appeal stage may indicate that people who are aware of it were not exposed enough to content and information to make the brand of MRT-J appealing for them.

\section{Ask}

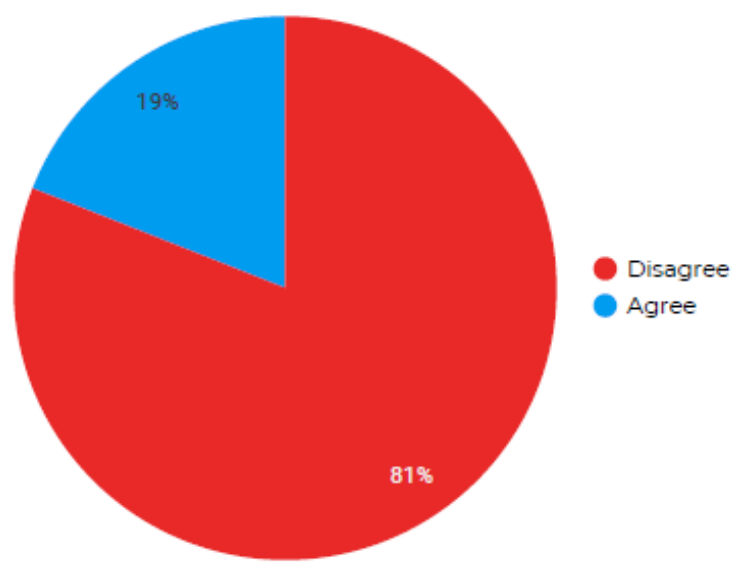

Source: Author's Analysis (2020)

Figure 4: Stage of Ask

The Ask stage is examined by asking if the respondents have ever asked about MRT Jakarta's mobile application to the MRT Jakarta officers, the contact center, friends, or searched online. The result informed that only $19 \%$ of the total respondents reached the Ask stage, as shown in Figure 4.

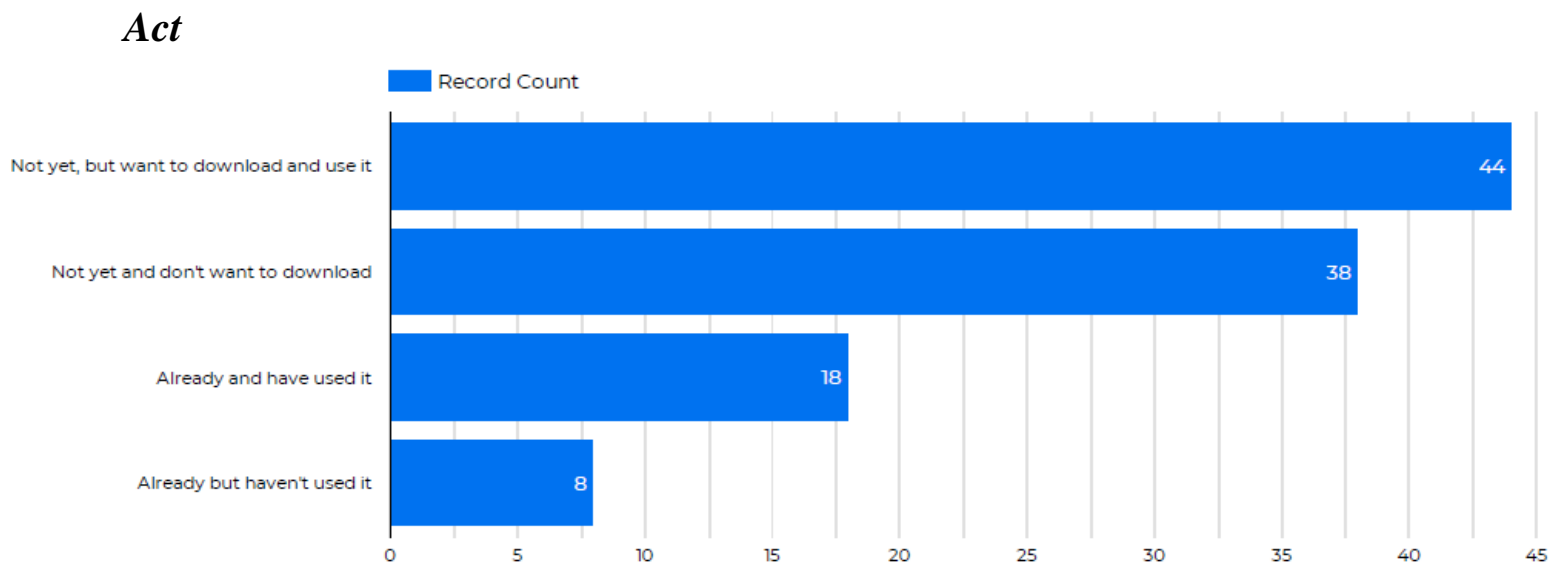

Source: Author's Analysis (2020)

Figure 5: Stage of Act

The Act stage for MRT-J mobile application refers to the people who downloaded the application. For general commodity products, the stage also represents the number of buyers. 
Volume 2 Issue 6 (December 2020) PP. 43-54 DOI 10.35631/AIJBES.26005

The result reported that there were only 26 MRT Jakarta's users or $12,68 \%$ of the total respondents who have downloaded the MRT-J mobile application, as shown in Figure 5.

\section{Advocate}

In the Marketing 4.0 concept, a brand's end goal is not the Act stage or when the targeted audience decides to purchase the product. It goes beyond that which reaches the Advocate stage. The Advocate stage is somewhat unique since the targeted audience may skip the Act stage but proceeds to the Advocate stage. It means that the targeted does not buy or use the product but acknowledge its quality or service. From the total respondents, Figure 6 reported that there were 98 respondents or $47,80 \%$ of the total respondents who want to recommend the MRT-J mobile application to other people. Categorization, based on the Act stage, revealed that $52 \%$ of the MRT-J mobile application's users want to recommend it, and $48 \%$ of the nonMRT-J mobile applications also want to recommend it.

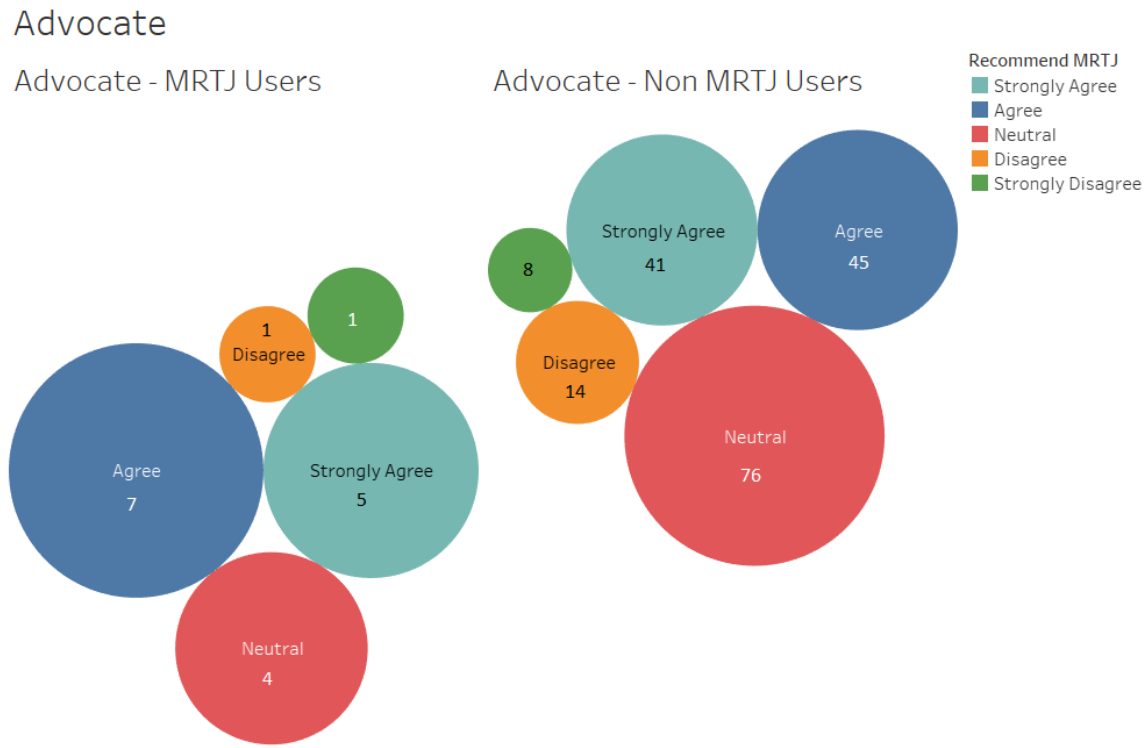

Source: Author's Analysis (2020)

\section{Marketing Productivity Metrics}

There are two brand productivity metrics examined after auditing the MRT-J mobile application's customer journey using the Five As Framework, PAR (Purchase Action Ratio), and BAR (Brand Advocacy Ratio). PAR informs the effectiveness of MRT-J as a brand in converting people's awareness into action, while BAR reveals the effectiveness of MRT-J as a brand in converting awareness into advocacy. PAR was calculated by dividing the level of the Act stage by the level of the Aware stage or 12,68 divided by 52,68, which is equal to 0,24 . The number indicates that 20 out of 100 people aware of the MRT-J mobile application decide to download it. BAR, on the other hand, was calculated by dividing the Advocate stage to the Aware stage or 47,80 divided by 52,68 , which is equal to 0,90 . The number informs that 90 out of 100 people aware of the MRT-J mobile application recommend it to others regardless of whether they have downloaded it.

As the perfect score for PAR and BAR is 1, the PAR and BAR evaluations of MRT-J reported that the MRT-J mobile application has a shallow score of PAR. Improving the PAR score is 
Volume 2 Issue 6 (December 2020) PP. 43-54 DOI 10.35631/AIJBES.26005

vital to increase the number of downloads of the MRT-J mobile application. However, further examination to detect the bottleneck is required to provide more specific insights and develop a more robust marketing strategy. Brand productivity metrics calculation can reveal at which level the MRT-J mobile application has to focus on to resolve the bottleneck. There are four levels to examine, which are the attraction, curiosity, commitment, and affinity. Table 1 reports that the bottlenecks of the customer journey of the MRT-J mobile application are attraction, curiosity, and commitment. It can be concluded that way since the MRT-J mobile application has a high-affinity score (376\%) but way far lower score of attraction, curiosity, and commitment levels were only one-sixth of the affinity level.

Table 1: MRT-J's Marketing Productivity Metric

\begin{tabular}{|c|c|c|c|c|c|}
\hline \multicolumn{6}{|c|}{ MRT-J } \\
\hline FIVE As & AWARE & APPEAL & ASK & $\mathbf{A C T}$ & ADVOCATE \\
\hline LEVEL (\%) & 52,68 & 31,70 & 19,00 & 12,68 & 47,80 \\
\hline $\begin{array}{l}\text { ATTRACTION } \\
\text { (Appel/Aware) }\end{array}$ & \multicolumn{2}{|c|}{0,60 or $60 \%$} & & & \\
\hline $\begin{array}{l}\text { CURIOSITY } \\
\text { (Ask/Appeal) }\end{array}$ & & \multicolumn{2}{|c|}{0,60 or $60 \%$} & & \\
\hline $\begin{array}{l}\text { COMMITMENT } \\
\text { (Action/Ask) }\end{array}$ & & \multicolumn{3}{|c|}{0,66 or $66 \%$} & \\
\hline $\begin{array}{l}\text { AFFINITY } \\
\text { (Advocate/Act) }\end{array}$ & & & & \multicolumn{2}{|c|}{3,76 or $376 \%$} \\
\hline
\end{tabular}

Bottleneck

Source: (Author's Analysis, 2020)

The result may indicate that people acknowledge the importance of the MRT-J mobile application to enhance the quality service of MRT Jakarta. However, not all people have been aware that PT MRT Jakarta has a mobile application for its users. Consequently, the brand is not well penetrated in the market. PT MRT Jakarta (Perseroda) needs to evaluate if the Company has developed enough marketing content and effort to promote MRT-J mobile application as a brand and evaluate if the current market marketing strategy is powerful enough to increase the attraction. The low level of curiosity may also indicate that the public has not been exposed enough with adequate information to ask questions to justify their understanding. The third one, commitment level, indicates that MRT-J does not provide enough added values to feel the urgency or importance to download it regardless of their affirmation of the usefulness or functionality.

\section{Industry Patter Archetype}

The evaluation of Aware, Appeal, Ask, Action, and Advocate yields an industry pattern archetype that could further verify customer behavior and industry characteristics. Kotler, Kartajaya, and Setiawan (2017) introduce four industry archetypes in Marketing 4.0: doorknob, goldfish, trumpet, and funnel with one ideal or perfect customer path pattern of a bowtie. 


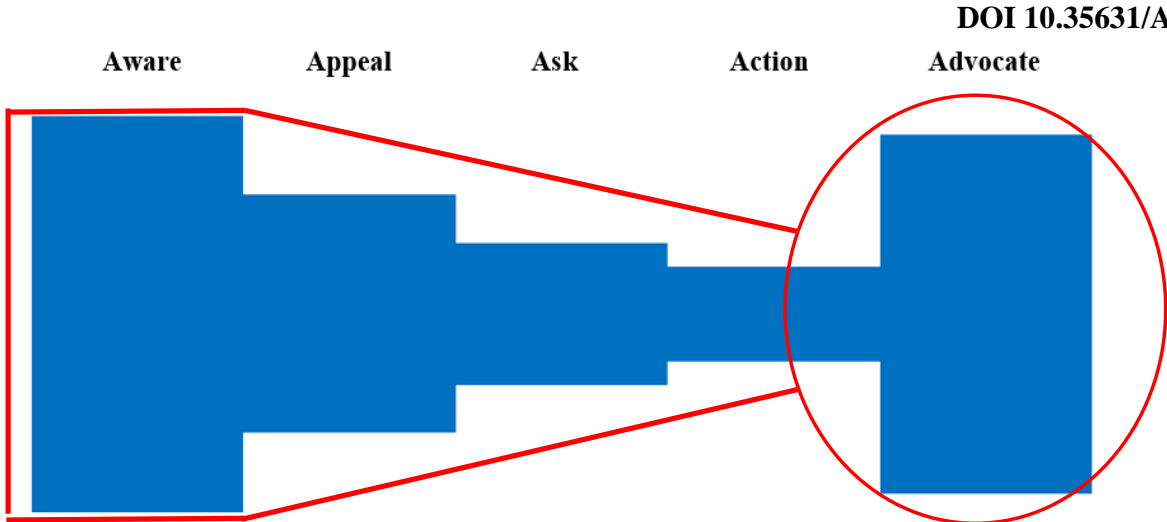

Figure 7: Industry Pattern Archetype

Source: Author's Analysis (2020)

The analysis report indicates that MRT-J belongs to the industry archetype's Trumpet pattern, as shown in Figure 7. With that pattern, it is identified that MRT-J as a brand has customers who are confident with the brand quality but still highly involved in a purchase decision.

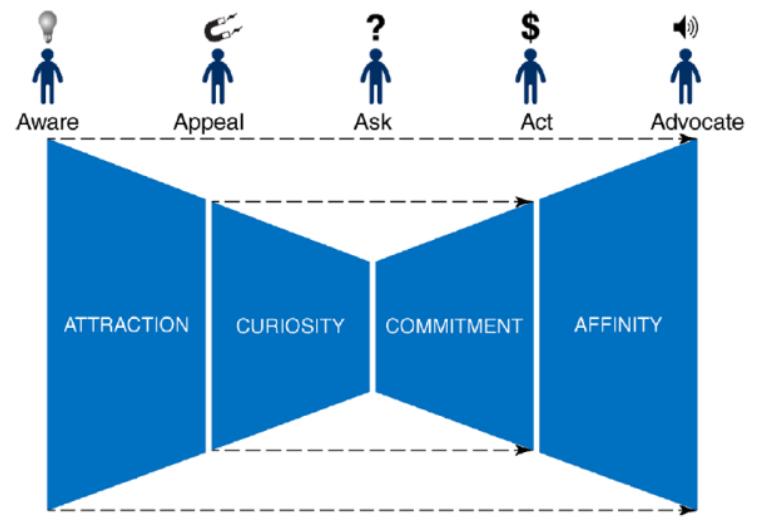

Figure 8: Bow Tie Pattern

The industry where MRT-J exists generally has a well-established reputation due to the proven quality and strong influence of word of mouth. Compared to a bowtie pattern, which is the perfect pattern shown in Figure 8, Trumpet has a lower commitment level. It means that the main gaps that the MRT-J mobile application has are Action and Ask stage. Enormously, the people who undergo Ask stage should be increased to raise the commitment level eventually.

\section{Conclusion and Recommendation}

The study reveals that MRT-J mobile application as a brand has a Trumpet pattern of industry archetype according to the Five As framework evaluation. The evaluation also reveals that MRT-J mobile application has a high-affinity level that needs to be maintained. MRT-J mobile application is seen as a quality product, which triggers people to recommend the utilization even if the advocators have not used the product yet. However, other evaluation results report that MRT-J needs to improve its attraction, curiosity, and commitment since these three elements were reported to be the bottleneck of the customer journey.

To improve the MRT-J mobile application's brand productivity, PT MRT Jakarta (Perseroda) has to focus on improving the effectiveness of Aware, Appeal, Ask, and Act stages. The Company needs to consider a combination of online and offline marketing strategies to improve those stages. Development of testimonial video or TVC can be options for improving Aware Copyright $\odot$ GLOBAL ACADEMIC EXCELLENCE (M) SDN BHD - All rights reserved 
Volume 2 Issue 6 (December 2020) PP. 43-54 DOI 10.35631/AIJBES.26005

stage. Appeal stage can be improved through digital and offline campaigns to increase public's familiarity with the MRT-J brand and Ask stage all at once. The Act stage can be leveraged through loyalty or referral programs that can engage both users and potential users. For the industry pattern, improving the Trumpet pattern to become a Bow Tie pattern can improve MRT-J features and added-values.

\section{References}

Ahearne, M., Bhattacharya, C. B., \& Gruen, T. (2005). Antecedents and consequences of customer-company identification: Expanding the role of relationship marketing. Journal of Applied Psychology, 90 (3), 574-585. DOI: https://doi.org/10.1037/00219010.90.3.574

Arya, V., Sethi, D., \& Paul, J. (2019). Does digital footprint act as a digital asset? Enhancing brand experience through remarketing. International Journal of Information Management, 49, 142-156. DOI: https://doi.org/10.1016/j.ijinfomgt.2019.03.013

Ayuverda, K \& Permana, D. (2020). Analysis of The Effect of Perceived Benefit and Perceived Ease on Consumer Interest in Using Single Trip Ticket of MRT Jakarta and The Impact on Buying Decision. Dinasti International Journal of Management Science Volume 2, Issue 1, September 2020. DOI: https://doi.org/10.31933/dijms.v2i1

APJII. (2017). Survei APJII 2017. Asosiasi Penyelenggara Jasa Internet Indonesia. Available in: https://apjii.or.id/survei2017

APJII. (2018). Survei APJII 2018. Asosiasi Penyelenggara Jasa Internet Indonesia. Available in: https://apjii.or.id/survei2018

Berger, J., \& Heath, C. (2007). Where consumers diverge from others: Identity signalling and product domains. Journal of Consumer Research, 34 (2), 121-134. DOI: https: // doi.org / 10.1086 / 519142.

Carroll, B.A. and Ahuvia, A.C. (2006), Some antecedents and outcomes of brand love. Marketing Letters. DOI: https://doi.org/10.1007/s11002-006-4219-2.

Fucui, M. (2018). From marketing 1.0 to marketing 4.0 - the evolution of the marketing concept in the context of the $21^{\text {st }}$ Century. International Conference Knowledge-Based Organization, June 2018. DOI: 10.1515/kbo-2018-0064

Goi, M. T., Goi, C. L., \& Wong, D. (2014). Constructing a brand identity scale for higher education institutions. Journal of Marketing for Higher Education, 24 (1), 59-74. DOI: https://doi.org/10.1080/08841241.2014.906017

Gregor, Bogdan. (2002). Evolution and modern concepts of marketing. Studia. Polska Akademia Nauk. Komitet Przestrzennego Zagospodarowania Kraju 112: 9-36.

Jara, AJ. (2012). Marketing 4.0: A new value added to the marketing through the Internet of Things. Sixth International Conference of Innovative Mobile and Internet Srvices in Ubiquitous Computing. DOI: 10.1109/IMIS.2012.203

Jasiulewicz, A \& Waskowski, Z (2020). Possibilities of Brand Promotion Through Lifestyle Mobile Sports Application. Marketing of Scientific and Research Organizations, 2020, Vol 37, Issue 3, p.1-16. DOI: 10.2478/minib-2020-0019

Kotler, Kartajaya H, and Setiawan I. (2017). Marketing 4.0: Moving from Traditional to Digital. New Jersey: John Wiley \& Sons, Inc.

Paul, J., \& Rosenbaum, M. (2020). Retailing and consumer services at a tipping point: New conceptual frameworks and theoretical models. Journal of Retailing and Consumer Services, 101977. DOI: https://doi.org/10.1016/j.jretconser.2019.101977.

Rajagopal, D. (2008). Interdependence of Personality Traits and Brand Identity in Measuring Brand Performance. SSRN. https://doi.org/10.2139/ssrn.1309864 
Volume 2 Issue 6 (December 2020) PP. 43-54 DOI 10.35631/AIJBES.26005

Ruvio, A. (2008). Unique like everybody else? The dual role of consumers' needs for uniqueness. Psychology and Marketing, 25 (5), 444-464. DOI: https://doi.org/10.1002/mar.20219

Swieczak, W. (2017). The Impact of Modern Technology on Changing Marketing Actions in Organizations Marketing 4.0. Minib, 2017, Vol 26, Issue 4, p.161-186. DOI: 10.14611/minib.26.12.2017.17

Tsaur, S. H., Yen, C. H., \& Yan, Y. T. (2016). Destination brand identity: Scale development and validation. Asia Pacific Journal of Tourism Research, 21 (12), 1310-1323. DOI: https://doi.org/10.1080/10941665.2016.1156003.

Verma, S \& Yadav, N. (2020). Past, Present, and Future of Electronic Word of Mouth (EWOM). Journal of Interactive Marketing 53 (2021) 111-128. DOI: https://doi.org/10.1016/j.intmar.2020.07.001

Wanke, M., Herrmann, A., \& Schaffner, D. (2006). Brand name influence on brand perception. Psychology \& Marketing Valume 24 Issue 1. DOI: http://doi.org/10.1002/mar.20150

Wereda, W and Wozniak, J. (2019). Building Relationships with Customer 4.0 in the Era of Marketing 4.0: The Case Study of Innovative Enterprises in Poland. Social Science. 2019, 8, 177. DOI: 10.3390/socsci8060177

World Bank. (2020). Aspiring Indonesia: Expanding the Middle Class. The World Bank. Available in: https://www.worldbank.org/en/country/indonesia/publication/aspiringindonesia-expanding-the-middle-class

Yeo, N.C.Y. Pepin, H. and Yang, S.S. (2017). Revolutionizing technology adoption for the remanufacturing industry. Procedia of the 24th CIRP Conference on Life Cycle Engineering, 17-21. DOI: https://doi.org/10.1016/j.procir.2016.11.262 